\title{
Neuronal Properties and Trophic Activities of Immortalized Hippocampal Cells from Embryonic and Young Adult Mice
}

\author{
Henry J. Lee, ${ }^{1}$ David N. Hammond, ${ }^{1,2,3}$ Thomas H. Large, ${ }^{6, a}$ John D. Roback, ${ }^{5}$ Joan A. Sim, ${ }^{7}$ David A. Brown, ${ }^{7}$ \\ Uwe H. Otten, ${ }^{8}$ and Bruce H. Wainer ${ }^{1,3,4,5}$ \\ ${ }^{1}$ Committee on Neurobiology and Departments of ${ }^{2}$ Pediatrics, ${ }^{3}$ Neurology, ${ }^{4}$ Pharmacological and Physiological Sciences, \\ and ${ }^{5}$ Pathology, The University of Chicago, Chicago, Illinois 60637, ${ }^{6}$ Howard Hughes Medical Institute, The University of \\ California, San Francisco, San Francisco, California 94143, ${ }^{7}$ Department of Pharmacology, University College London, \\ London, England, and ${ }^{8}$ Department of Pharmacology, Biocenter of the University of Basel, Basel, Switzerland
}

\begin{abstract}
The hippocampal formation elaborates trophic factors such as nerve growth factor (NGF) to support the cholinergic innervation it receives from the septal region. To further study the trophic interactions of this pathway, hippocampal cells from embryonic day 18 and postnatal day 21 mice were immortalized via somatic cell fusion to N18TG2 neuroblastoma cells. The hippocampal cell lines exhibit morphological and cytoskeletal features which are typical of their neuronal parents but which are not expressed by the neuroblastoma parent. When differentiated with retinoic acid, the hippocampal cell lines exhibit electrophysiological features similar to cultured hippocampal neurons. Many of the lines constitutively express high levels of NGF, and at least one cell line exerts a non-NGF trophic effect on the expression of choline acetyltransferase by septal neurons in vitro. These cell lines are potentially useful for investigating the neurochemical and excitable properties of hippocampal neurons and identifying novel trophic activities that promote the development and maintenance of the septohippocampal pathway.
\end{abstract}

Trophic interactions between projecting neurons and their targets are thought to mediate the development and maintenance of specific neural connections. In the CNS, the hippocampal formation trophically supports innervating septal cholinergic neurons by promoting their survival and expression of cholinergic markers (Gähwiler and Hefti, 1984; Gähwiler and Brown, 1985; Hsiang et al., 1987, 1988). Nerve growth factor (NGF) appears to play an important role since it is synthesized by

\footnotetext{
Received Sept. 7, 1989; revised Dec. 1, 1989; accepted Dec. 21, 1989.

We thank E. M. Eves, A. H. Heller, P. C. Hoffmann, and M. D. Tanklefsky for advice; P. Benjamin, R. M. Demuth, S. N. Nelson, S. D. Price, L. J. Sherman and J. D. Zucker for expert technical assistance; Dr. V. M-Y. Lee for supply of antibodies against neurofilament proteins, and Dr. W. C. Mobley for supply of NGF. This investigation was supported by NIH grants HD070009 (H.J.L.) NS01244 (D.N.H.), and NS25787 (B.H.W.); the Medical Research Council (J.A.S., D.A.B.); Fonds National Suisse de la Recherche Scientifique grant 31-25690.88 (U.H.O.); and grants from the Alzheimer's Disease and Related Disorders Association, Illinois Department of Public Health, and the John Douglas French Foundation. Additional support was provided by Louis F. Reichardt through the Howard Hughes Medical Institute at UCSF and NIH grant NS21824. D.N.H. is a Daland Fellow in Medical Research of the American Philosophical Society.

Correspondence should be addressed to Bruce H. Wainer, Department of Pharmacological and Physiological Sciences, The University of Chicago, 947 E. 58th Street, Box 271, Chicago, IL 60637.

a Present address: Center for Neurosciences, Case Western Reserve University School of Medicine, Cleveland, OH 44106.
}

Copyright (c) 1990 Society for Neuroscience $0270-6474 / 90 / 061779-09 \$ 02.00 / 0$ hippocampal cells and partially mimics their trophic effects (for review, see Whittemore and Seiger, 1987; see also Hartikka and Hefti, 1988, and Hsiang et al., 1989). However, antibody-mediated neutralization of endogenous NGF does not block cholinergic synaptogenesis in co-cultures of septum and hippocampus (Hsiang et al., 1989) or dramatically alter the expression of septal cholinergic markers (Gnahn et al., 1983; Hsiang et al., 1989; Vantini et al., 1989). These results suggest that NGF and an unknown number of other trophic factors influence the differentiation of septal cholinergic neurons.

To study these processes in more detail, we have generated clonal cell lines of CNS lineage. Two strategies have been used to engineer such lines cell lines: retroviral-mediated oncogene transduction and somatic cell fusion. Stable introduction of transforming or immortalizing DNA is effective only with cells that retain the capacity to replicate DNA and therefore divide (Cepko, 1988). In addition, once a cell is "immortalized," it tends to remain locked within a particular developmental window (Paige and $\mathrm{Wu}, 1989$ ). Therefore, while oncogene transduction might yield cell lines to study the early stages of neural development (e.g., Frederiksen et al., 1988), it is less likely to provide cell lines that express the phenotypic repertoire of mature neurons. Somatic cell fusion permits the "immortalization" of cell populations that are postmitotic (Lee et al., 1990) and thus more likely to express highly differentiated neuronal phenotypes.

We have previously generated cell lines with cholinergic properties from the septal region of mice (Hammond et al., 1986, 1990; Lee et al., 1990). In the present paper, we describe the immortalization of hippocampal cells from embryonic and young adult mice. Fusion of hippocampal cells to N18TG2 neuroblastoma cells resulted in phenotypically stable hybrid cell lines that express neuronal cytoskeletal elements, exhibit electrophysiological behaviors typical of hippocampal neurons, and synthesize high levels of NGF. Moreover, at least one cell line exerts a trophic influence on septal cholinergic neurons that does not appear to be attributable to NGF, epidermal growth factor, or basic fibroblast growth factor.

\section{Materials and Methods}

Animals and cell lines. C57BL/6 mice (Harlan Sprague-Dawley) were employed as the source of primary hippocampal cells. These cells express hypoxanthine phosphoribosyltransferase (HPRT) and the B electrophoretic variant of glucose phosphate isomerase (GPI) (Greene et al., 1975; Lee et al., 1990). The neuroblastoma fusion partner was the N18TG2 line, an HPRT-deficient mutant which can be eliminated from cultures by supplementing the medium with $100 \mu \mathrm{M}$ hypoxanthine, 
$0.4 \mu \mathrm{M}$ aminopterin, and $16 \mu \mathrm{M}$ thymidine (HAT medium; Gibco) (Greene et al., 1975; Lee et al., 1990). N18TG2 cells revert to the normal state at a rate of less than $10^{-7} / \mathrm{cell} /$ generation (Greene et al., 1975) and were routinely grown in $100 \mu \mathrm{M}$ 6-thioguanine to eliminate revertants. The neuroblastoma was originally isolated from an $\mathrm{A} / \mathrm{J}$ strain mouse and thus expresses the A isozyme variant of GPI (Greene et al., 1975; Lee et al., 1990). For all cultures, the basic medium was composed of Dulbecco's modified Eagle's medium (DMEM) supplemented with $10 \%$ fetal calf serum (culture medium; Gibco) and was changed every 2-3 d. All assays and staining procedures were performed with hippocampal

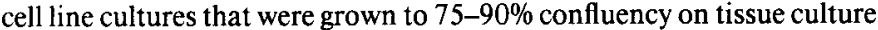
plastic.

Somatic cell fusion. The procedures for somatic cell fusion of embryonic or adult neural tissue to N18TG2 cells have been previously described (Hammond et al., 1990; Lee et al., 1990). Briefly, embryonic day 18 or postnatal day 21 hippocampi were isolated, incubated with trypsin, and dissociated into single cells by trituration. The postnatal hippocampal cell preparation contained numerous debris and was subjected to buoyant density centrifugation to isolate a fraction enriched for viable, singly dissociated cells (Lee et al., 1990). The hippocampal cells were then resuspended in phytohemagglutinin (PHAP; Difco) to promote their adherence to N18TG2 cells.

The hippocampal-PHAP suspensions were layered over logarithmically dividing N18TG2 cells. After $15 \mathrm{~min}$, unattached hippocampal cells were gently aspirated. Cell fusion was initiated by adding a $50 \%$ polyethylene glycol (PEG 1000; KochLight) in DMEM (vol/vol). After $40 \mathrm{sec}$, the solution was slowly aspirated, and at $60 \mathrm{sec}$ the cells were quickly rinsed. The fusion products were incubated overnight in culture medium and then replated in HAT medium to select for the growth of hybrid cells. The aminopterin was removed from the medium after 4 8 weeks; the hypoxanthine and thymidine were removed 4 weeks later. Colonies of hybrid cells were isolated, subcloned, and maintained in culture medium. Embryonic hippocampus $\times$ neuroblastoma lines are referred to as "HN\#e" lines, and postnatal hippocampus $\times$ neuroblastoma lines are referred to as "HN\#p" lines. Subclones of these cell lines contain a period in their names (e.g. " $\mathrm{HN} 9.10 \mathrm{e}$ " refers to a subclone of embryonic hippocampus $\times$ neuroblastoma cell line HN9e).

Control fusions included N18TG2 $\times$ N18TG2 and hippocampus $\times$ hippocampus fusions. Dissociated N18TG2 cells were incubated with PHAP, fused to preplated N18TG2 cells, and then cultured as described for the hippocampus $\times$ N18TG2 fusions. Dissociated primary hippocampal cells were incubated with PHAP, fused to preplated hippocampal cells, and then cultured as described for the hippocampus $\times$ N18TG2 fusions.

The hybrid nature of the cell lines was confirmed by analyzing GPI isozyme electrophoretic migration patterns as previously described (Lee et al., 1990).

Immunofluorescence. Hippocampal lines (HN9e, HN10e, HN25p, $\mathrm{HN} 32 \mathrm{p}$, and HN33p) and the N18TG2 neuroblastoma were grown on plastic Lab-Tek chamber slides (Miles), fixed with $2 \%$ formaldehyde in methanol $\left(-15^{\circ} \mathrm{C}\right)$ for $5 \mathrm{~min}$ at $0^{\circ} \mathrm{C}$, and incubated with a mouse antibody (RMO108) directed against the middle-molecular-weight neurofilament subunit protein (Lee et al., 1987) for $12 \mathrm{hr}$ at $4^{\circ} \mathrm{C}$. Immunoreactivity was visualized by incubating the cells with rabbit antimouse IgG conjugated to rhodamine (Dakopatts) for $12 \mathrm{hr}$ at $4^{\circ} \mathrm{C}$. After staining, the slides were mounted in $p$-phenylenediamine-buffered glycerol to preserve fluorescence, coverslipped, and sealed with fingernail polish. The cells were examined with a Leitz microscope equipped with epifluorescence and then photographed. Negative controls were performed by using mouse IgG as the primary antibody (Lee et al., 1989, 1990).

NGF ELISA and Northern blot analysis of hippocampal lines. NGF protein was quantitated with a 2-site enzyme-linked immunoassay (ELISA) specific for $\beta$-NGF (Weskamp and Otten, 1987; Lee et al., 1990). Briefly, samples from hippocampal cell line cultures (HN8e, HN9.10e, HN10e; HN25.1p, HN25.2p; and HN33.11p) were applied to microtiter plates (Immuno-Plate I, Nunc) which had been previously coated with goat anti- $\beta$ NGF. Bound NGF was visualized by scrially incubating the wells with monoclonal antibody to $\beta-N G F$, biotinylated goat anti-rat IgG (Zymed), HRP conjugated to streptavidin (Zymed), and $o$-phenylenediamine (Sigma). Absorbance values of the samples were compared with values obtained from known quantities of purified male mouse submaxillary $\beta$-NGF (Mobley et al., 1986). Background signal was obtained by coating wells with preimmune goat serum rather than the anti-NGF serum. The NGF ELISA has a sensitivity of $0.1-1$ $\mu \mathrm{g}$ NGF per assay, and recovery of NGF from the samples was routinely $90-100 \%$. Total protein concentration of each sample was determined by the method of Bradford (1976) (BioRad).

To measure NGF mRNA expression by cell lines, Northern blot analysis was performed as described by Clegg et al. (1989). Total RNA was isolated by lysing hippocampal cell line cultures with guanidinium isothiocyanate, precipitating the RNA with ethanol, and then extracting the RNA with phenol and chloroform. After determining the RNA content spectrophotometrically, $25 \mu \mathrm{g}$ of total RNA per lane was electrophoresed through a $1.5 \%$ agarose-formaldehyde gel, capillary blotted onto GeneScreen (New England Nuclear), and covalently cross-linked to the membrane with UV irradiation. NGF mRNA was detected with a ${ }^{32}$ P-labeled single-stranded cDNA probe synthesized from the large Pst I fragment of a NGF cDNA clone (Scott et al., 1983). The blots were exposed to X-ray film (Kodak XAR-5) with an intensifying screen at $-70^{\circ} \mathrm{C}$. Autoradiograms were quantified with a laser densitometer. All gels contained standards of unlabeled NGF mRNA synthesized in vitro (Clegg et al., 1989). The specific signal for NGF mRNA was normalized to total RNA per lane.

Differentiation and electrophysiology. HN9.10e or HN33.11p cells were plated at $1-5 \times 10^{5}$ cells $/ 30 \mathrm{~mm}$ tissue culture dish. After $24 \mathrm{hr}$ the cells were treated with DMEM containing $1 \%$ fetal calf serum and $2-10 \mu \mathrm{M}$ retinoic acid. After 2-8 d, the dishes were mounted onto the stage of an inverted-phase microscope (Nikon TMS) and superfused (3$5 \mathrm{ml} / \mathrm{min})$ at room temperature $\left(20-30^{\circ} \mathrm{C}\right)$ with a bicarbonate buffered salt solution (in mM: $\mathrm{NaCl}, 118 ; \mathrm{KCl}, 3 ; \mathrm{MgCl}_{2}, 1.2 ; \mathrm{CaCl}_{2}, 2.5 ; \mathrm{NallCO}_{3}$, 25; D-glucose, 11; HEPES, 40; $\mathrm{pH} 7.4$ when bubbled with $95 \% \mathrm{O}_{2}: 5 \%$ $\mathrm{CO}_{2}$ ).

Isolated pyramidal-shaped cells of $25-80 \mu \mathrm{m}$ in diameter, and possessing neuritic processes, were chosen for recording using single-patch electrodes in a whole-cell recording configuration as described by Hamill et al. (1981). The patch electrodes had resistances of 4-6 M $\Omega$ when filled with the internal solution (in $\mathrm{mM}$ : $\mathrm{K}$ acetate, 90; $\mathrm{KCl}$, 20; HEPES, 40; $\mathrm{MgCl}_{2}$, 3; EGTA/KOH, 3; ATPNa, $1 ; \mathrm{pH}$ 7.4). The electrode tip was sealed to a cell by suction (seal resistance $>500 \mathrm{M} \Omega$, usually $2-5 \mathrm{G} \Omega$ ) and the membrane patch disrupted by further suction. The superfusate was connected to a grounded electrode via a $3 \mathrm{M} \mathrm{KCl}$-agar bridge. After successfully establishing whole-cell recording, the cell was either currentor voltage-clamped using a single-electrode current-voltage preamplifier (Axoclamp-2A, Axon Instruments Inc.) in switching mode operating at 3-6 kHz. Capacitance neutralization, gain, and phase were adjusted to give optimum point-clamp efficiency as described by Finkel and Redman (1984). Data were recorded on a chart recorder (Gould 2400S).

Preparation of hippocampal cell line conditioned media. Twenty-two hippocampal cell lines or N18TG2 cells were grown on tissue culture plastic in culture medium to $75-95 \%$ confluency. The plates were rinsed 5 times with serum-free DMEM, and then incubated for $24-36 \mathrm{hr}$ in serum-free DMEM. The conditioned medium was collected and centrifuged at $1000 \times g$ for $20 \mathrm{~min}$ at $4^{\circ} \mathrm{C}$. The supernatant was subsequently centrifuged at $100,000 \times g$ for $90 \mathrm{~min}$ at $4^{\circ} \mathrm{C}$. The $100,000 \times g$ supernatant was concentrated under nitrogen pressure in an Amicon stirred cell equipped with an Amicon YM5 filter (5000 Dal cutoff). The concentrated retentate was then aliquoted and frozen in liquid nitrogen. Protein concentration was measured using Bio-Rad protein assay dye reagent, with BSA standards.

Bioassay for cholinotrophic activities. To screen hippocampal cell lines for the expression of trophic activities which influence cholinergic basal forebrain cells, a microtiter bioassay system employing primary cells from the septal region was developed. Microtiter plates were coated with poly-L-lysine $(50 \mu \mathrm{g} / \mathrm{ml}$ in borate buffer). The septal region of embryonic day 14-15 mice were dissected and dissociated as previously described (Hsiang et al., 1987). The cells were resuspended in serumfree DMEM containing insulin $(5 \mu \mathrm{g} / \mathrm{ml})$, transferrin $(10 \mu \mathrm{g} / \mathrm{ml})$, selenite $(30 \mathrm{nM})$, progesterone $(20 \mathrm{nM})$, putrescine $(100 \mu \mathrm{M})$, glutamine $(584 \mu \mathrm{g} /$ $\mathrm{ml})$, and gentamicin $(20 \mu \mathrm{g} / \mathrm{ml})(\mathrm{N} 2$ medium; Gibco) (Bottenstein and Sato, 1985). The cells were then plated on the microtiter plates at 300,000 cells/well. Media conditioned by N18TG2 or by hippocampal cell lines (prepared as described above) were added to some wells. Other wells received purified NGF, epidermal growth factor, basic fibroblast growth factor (both from Collaborative Research), or N2 medium alone. The septal cells were cultured for $7-9 \mathrm{~d}$, and then processed for CAT activity measurement.

The CAT assay was modified from Fonnum (1975) so that it could be performed in the same microtiter wells that the cells were grown in. At the conclusion of the culture period, the wells were gently rinsed 


\begin{tabular}{|c|c|c|c|c|c|c|c|}
\hline $\begin{array}{l}\text { Tissue or } \\
\text { cell line }\end{array}$ & $\begin{array}{l}\text { Hybrid } \\
\text { GPI } \\
\text { isozyme }\end{array}$ & $\begin{array}{l}\text { Neuritic } \\
\text { pro- } \\
\text { cesses }\end{array}$ & $\begin{array}{l}\text { Excitable } \\
\text { membrane }\end{array}$ & NF-M & $\begin{array}{l}\text { NGF } \\
\text { protein }\end{array}$ & $\begin{array}{l}\text { NGF } \\
\text { mRNA }\end{array}$ & $\begin{array}{l}\text { Non-NGF } \\
\text { trophic } \\
\text { activity }\end{array}$ \\
\hline Hippocampus & - & + & + & + & $+^{a}$ & $+^{a}$ & $+^{b}$ \\
\hline N18TG2 & - & - & $-c$ & - & - & - & - \\
\hline HN8e & & + & & + & + & + & - \\
\hline HN9e & + & + & + & + & + & + & - \\
\hline HN10e & & + & & + & + & + & + \\
\hline HN25p & + & + & & + & + & + & \\
\hline HN33p & + & + & + & + & + & + & \\
\hline
\end{tabular}

The hybrid cell lines were generated by fusing embryonic day 18 or postnatal day 21 hippocampal cells to N18TG2 neuroblastoma cells (HN\#e and HN\#p, respectively). The properties of the best characterized hippocampal lines are summarized ahove. Data for each cell line include properties of their subclones. Symbols: + , presence of trait; - , absence of trait; spaces, line was not tested for the trait. Abbreviations: GPI, glucose phosphate isomerase; NF-M, middlemolecular-weight neurofilament subunit protein; NGF, nerve growth factor.

¿ Large et al., 1986

${ }^{b}$ Hsiang et al., 1989.

Platika et al., 1985.

twice with ice-cold Tyrode's buffer (in mM: $\mathrm{NaCl}, 137 ; \mathrm{KCl}, 2.5 ; \mathrm{CaCl}_{2}$, $2 ; \mathrm{MgCl}_{2}, 0.5 ; \mathrm{NaH}_{2} \mathrm{PO}_{4}, 3.5 ; \mathrm{NaHCO}_{3}, 12 ;$ glucose, $5.5 ; \mathrm{pH}$ 7.4). Each well received $50 \mu \mathrm{l}$ citrate phosphate buffer $(10 \mathrm{mM}, \mathrm{pH} 7.4)$ containing $0.1 \%$ Triton $\mathrm{X}-100$, was subjected to one freeze-thaw cycle, and then was warmed to $37^{\circ} \mathrm{C}$. Fifty microliters of enzyme assay medium (Hsiang et al., 1989) containing ${ }^{3} \mathrm{H}$-acetyl-CoA (Amersham) and eserine (Sigma) were added to each well. Following incubation at $37^{\circ} \mathrm{C}$ for $50 \mathrm{~min}$, the incubation mixture was transferred into a vial containing an ACh extraction and scintillation mixture (Hsiang et al., 1989). Background signal was determined by assaying citrate-phosphate buffer instead of the cell extract. CAT activity was calculated by subtracting background counts of radinactivity from those of experimental samples. Counting efficiency was corrected using a computer-generated quench curve. The CAT activities of treated wells were compared to that of wells receiving only $\mathrm{N} 2$ medium (control wells), and the $\mathrm{C} \Lambda \mathrm{T}$ activity results expressed as a percentage of control. The specificity of the CAT assay has been previously established (Fonnum, 1975; Levey et al., 1983).

\section{Results}

General characteristics of hippocampal cell lines. Following fusion, visible colonies of hybrid cells were observed at 2 weeks. Twelve colonies from the embryonic hippocampal fusion and 23 colonies from the young adult fusion were isolated and expanded. When subcloned at limiting dilutions, these hybrid lines had a cloning efficiency of approximately $20 \%$. All hippocampal lines were mononucleate as determined visually and through counts of nuclei versus cell number. The properties of the most extensively characterized hippocampal lines are summarized in Table 1. No viable colonies were isolated from fusions between N18TG2 cells only or hippocampal cells only.

The hybrid nature of hippocampal lines selected through HAT medium was confirmed through GPI isozyme analysis. GPI normally exists as a homodimer and has several variants which can be identified through electrophoresis (Staats, 1980). Table 2 shows that C57BL/6 hippocampal tissues expressed only the B isozyme variant of GPI, while N18TG2 (A/J) cells expressed only the $\mathrm{A}$ isoenzyme variant. Mixtures of $\mathrm{C} 57 \mathrm{BL} / 6$ tissue and N18TG2 cells yielded both homodimer bands but no heterodimeric band. Hippocampal lines exhibited GPI of intermediate electrophoretic mobility as well as both homodimers (Table 2). The heterodimeric or $\mathrm{AB}$ enzyme indicated that the lines were the result of a fusion between C57BL/6 and N18TG2 cells and that the lincs wcre able to express genes from both parental cell types simultaneously (Lee et al., 1990).

Morphology. Many hybrid cell lines grew attached to the culture dish and displayed differentiated morphologies (Fig. 1). For example, HN9e consisted of phase-bright cells with triangular somata and apical processes (Fig. 1A). This hippocampal line grew as a monolayer of cells. Other lines such as HN3lp grew as cell aggregates that were interconnected by a network of processes 2-3 days after plating (Fig. $1 B$ ). The processes were attached to adjacent aggregates more frequently than open spaces on the tissue culture plate (Fig. $1 B$ ). Five to seven days after plating, the aggregates were connected by columns of cells (Fig. 1C). In contrast to the hippocampal lines, the neuroblastoma parent cells had flat cell bodies, short processes, and always grew as a monolayer (Fig. $1 D$ ). The age of the hippocampal tissue did not seem to be a major determinant of the types of morphologies exhibited by the hippocampal lines or the level of morphological differentiation.

Expression of neurofilaments. Neurofilaments are a class of

\begin{tabular}{llll}
\hline $\begin{array}{l}\text { Table 2. Analysis of glucose phosphate isomerase expression by } \\
\text { representative C57BL/6 hippocampus } \times \text { N18TG2 neuroblastoma cell }\end{array}$ \\
lines \\
$\begin{array}{llll}\text { C57BL/6 } \\
\text { variant } \\
\text { of GPI } \\
\text { (IA) }\end{array}$ & $\begin{array}{l}\text { N18TG2 } \\
\text { variant } \\
\text { of GPI }\end{array}$ & $\begin{array}{l}\text { Hybrid } \\
\text { (IB) }\end{array}$ & (IAB) \\
(IAB) \\
Sample & & + & \\
\hline C57BL/6 & + & & \\
N18TG2 & & & \\
Mixture of C57BL/6 & & + & \\
and N18TG2 & + & + & + \\
HN9e & + & + & + \\
HN21p & + & + & + \\
HN32p & + & + & + \\
HN33p & + & + & + \\
\hline
\end{tabular}

C57BL/6 tissue expresses only the IB homodimer of glucose phosphate isomerase (GPI), whereas the N18TG2 neuroblastoma expresses only the IA homodimer. Mixtures C57BL/6 tissue and N18TG 2 cells exhibit only the 2 homodimers. The expression of a heterodimeric form of GPI (IAB) by several hippocampal lines indicates that they contain hybrid genomes. 

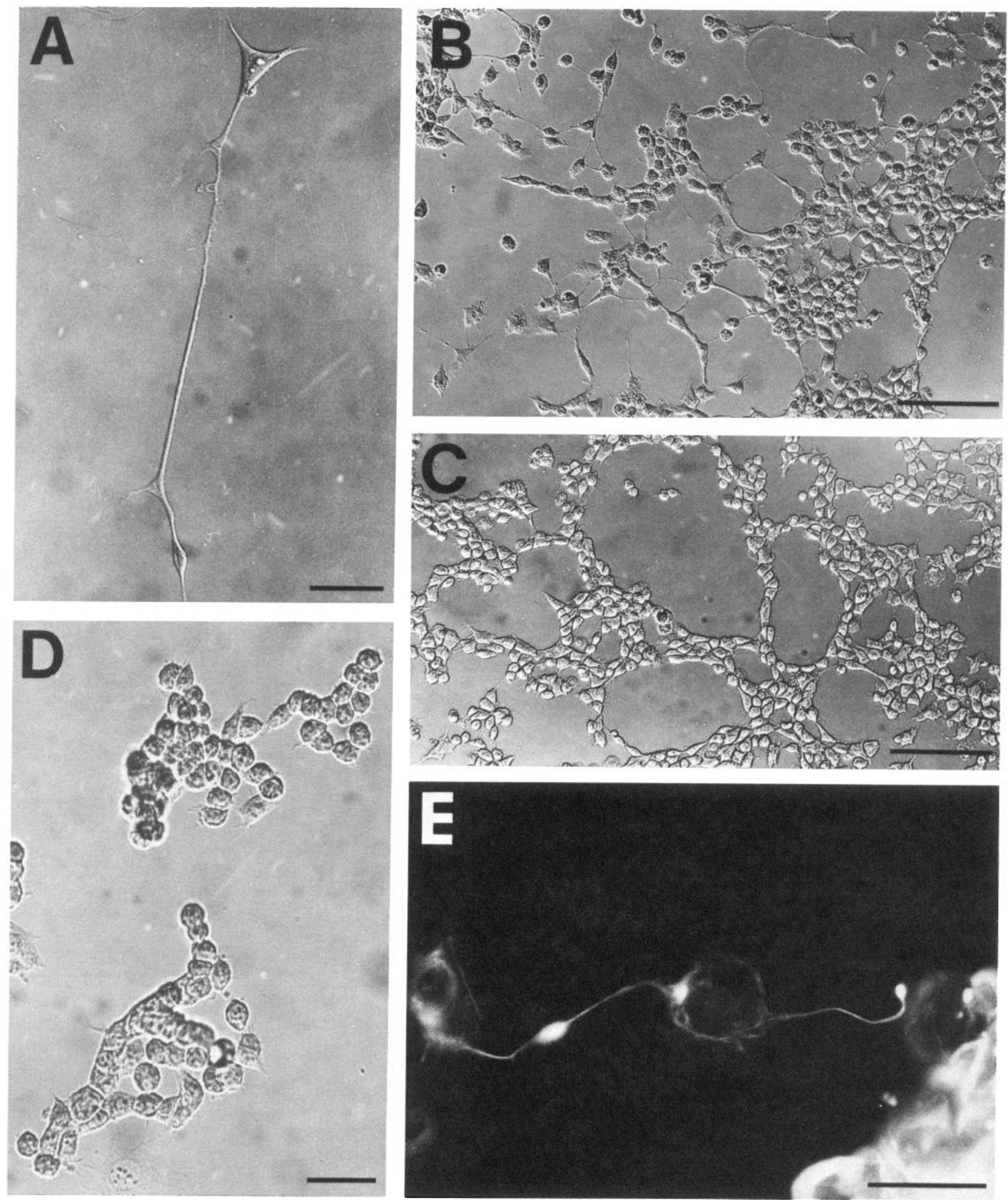

Figure 1. Photomicrographs demonstrating the morphology and neurofilament protein staining of representative embryonic hippocampus $\times$ N18TG2 and postnatal hippocampus $\times$ N18TG2 cell lines (HN\#e and HN\#p, respectively). All cells were grown in $10 \%$ fetal calf serum in Dulbecco's modified Eagle's medium on tissue culture plastic. A, HN9e grew as a monolayer of cells that exhibited phase-bright somata and extensive process formation. Note that the cells were cultured in the absence of cAMP, phorbol esters, or other differentiating agents. Scale bar, $25 \mu \mathrm{m} . B, \mathrm{HN} 31 \mathrm{p}$ grew as clusters of cells with processes attached to other clusters rather than open spaces on the tissue culture plate. Scale bar, $50 \mu \mathrm{m}$. $C$, As HN31p cells continue to grow and proliferate, the cell clusters become connected by cell bodies. Scale bar, $50 \mu \mathrm{m}$. $D$, N18TG2 neuroblastoma cells exhibit flat, polygonal somata with little process formation. The morphology of N18TG2 cells can range from round to fusiform. Scale bar, $25 \mu \mathrm{m}$. E, HN25p cells were fixed with $2 \%$ formaldehyde in methanol and incubated with the monoclonal antibody RMO108 directed 


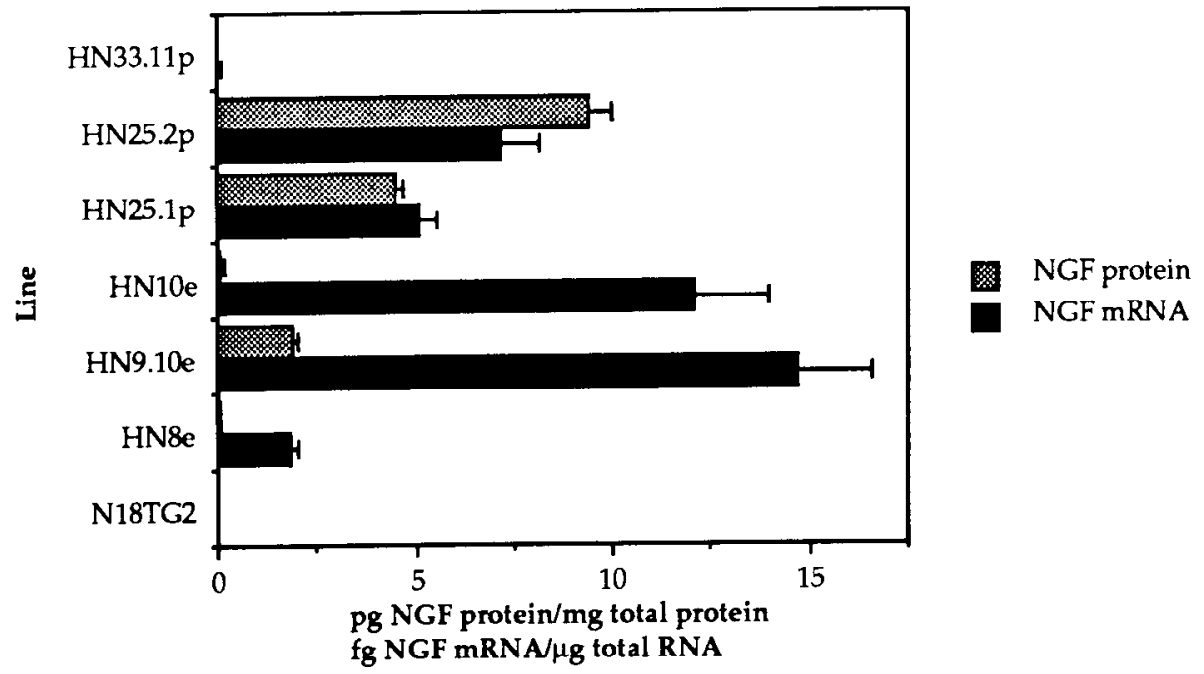

Figure 2. NGF protein and mRNA content of representative hippocampal cell lines. Hippocampal lines and N18TG2 cells were grown to $75 \%$ confluency in $10 \%$ fetal calf serum in Dulbecco's modified Eagle's medium and then assayed. NGF protein content (shaded bar) was determined with a 2-site enzyme-linked immunoassay specific for $\beta$-NGF and normalized to total protein in the samples (Weskamp and Otten, 1986; Lee et al., 1990). NGF mRNA content (solid bar) was determined by Northern blot analysis. Blots of total RNA were hybridized with a ${ }^{32}$ P-labeled DNA probe made from the $0.9 \mathrm{~kb}$ Pst I fragment of the NGF gene comprising a portion of the coding sequence as well as the 5 untranslated region (Scott et al., 1983; Large et al., 1986). Autoradiograms were quantified by scanning laser densitometry and normalized to total RNA per lane. HN8e, HN9.10e, and HN10e were derived from embryonic day 18 hippocampal cells. HN25.1p, HN25.2p, and HN33.1 lp were derived from postnatal day 21 hippocampal cells. Error bars indicate SEM.

intermediate filaments which serve as specific markers for neurons (Lee et al., 1987). Several hippocampal lines exhibiting neuronal morphologies were screened for neurofilament expression using immunofluorescence. HN9e, HN25p, and HN33p contained the middle-molecular-weight neurofilament subunit. HN25p exhibited the most robust staining and is shown in Figure $1 E$. The neurofilament subunit appeared to be a component of discrete filaments in the cell body and was preferentially distributed into the processes and growth cones (Fig. $1 E$ ). N18TG2 cells did not stain for any of the neurofilament triplet proteins in any of their phosphorylation states (Lee et al., 1989).

Expression of NGF. NGF expression by the hippocampal lines was quantified through 2-site ELISA and Northern blot analysis. Several lines expressed high levels of NGF protein or mRNA (Fig. 2). Figure 2 demonstrates that lines derived from postnatal day 21 hippocampal lines synthesized more NGF protein than embryonic derived lines but contained less NGF mRNA. HN$25.2 \mathrm{p}$ contained the most NGF protein ( $9 \mathrm{pg} \mathrm{NGF/mg} \mathrm{total}$ protein) and a relatively moderate amount of NGF mRNA (7.2 fg NGF mRNA/ $\mu$ g total RNA). Of the embryonic lines, HN9.10e contained the highest level of NGF protein (2 pg NGF/mg total protein) and synthesized high levels of NGF mRNA ( $15 \mathrm{fg} \mathrm{NGF}$ mRNA/ $\mu$ g total RNA) (Fig. 2). The hippocampal lines did not require the presence of differentiating agents to express NGF. N18TG2 cells contained no detectable NGF protein or mRNA (Fig. 2).

Electrophysiology. To characterize the excitable properties, hippocampal hybrid cell lines HN9.10e and HN33.11p cells were differentiated with retinoic acid and then examined using the whole-cell patch technique (Sakmann and Neher, 1983). Differentiated HN9.10e cells were found to have resting membrane potentials between -30 and $-60 \mathrm{mV}$ and membrane input resistances of $100-400 \mathrm{M} \Omega$. In 5 of 20 cells recorded, an action potential could be elicited by depolarizing steps from membrane potentials more negative than $-60 \mathrm{mV}$. Figure $3 A$ illustrates a typical action potential elicited by a depolarizing step of $+0.02 \mathrm{nA}$ in a cell held at $-80 \mathrm{mV}$ (with steady current injection). As shown, the action potential had an amplitude of $100 \mathrm{mV}$ (reaching $+20 \mathrm{mV}$ ) and was usually followed by a characteristic after depolarization which reached its peak value $10-30 \mathrm{msec}$ after the initial peak. Switching to voltage-clamp recording mode, the underlying transient inward current, corresponding to the action potential, could be recorded during depolarizing voltage steps to potentials between -40 and -15 $\mathrm{mV}$ (Fig. $3 B$ ) from a holding potential of $-80 \mathrm{mV}$.

In all 20 cells examined, pronounced outward potassium $(\mathrm{K}+)$ currents were recorded. Two second depolarizing steps from a holding potential of $-70 \mathrm{mV}$ evoked a sustained outward current with a threshold of about $-20 \mathrm{mV}$ (Fig. 3C). At command potentials positive to $0 \mathrm{mV}$, this outward current showed an additional inactivating component. When inactivation at +10 $\mathrm{mV}$ was removed by a priming prepulse to hyperpolarized potentials (Fig. $3 D$ ), the resultant inactivating current so isolated showed 2 components of decay, with time constants of about $800 \mathrm{msec}$ and $2 \mathrm{sec}$. This outward current was reversibly reduced by $\mathrm{K}^{+}$channel blockers: 4 -aminopyridine (4-AP: $100-300 \mu \mathrm{M}$ ) and tetraethylammonium (TEA: $1 \mathrm{~mm}$ ).

Figure $3 D$ also shows the presence of an inward current activated by hyperpolarization in a time- and voltage-dependent

$\longleftarrow$

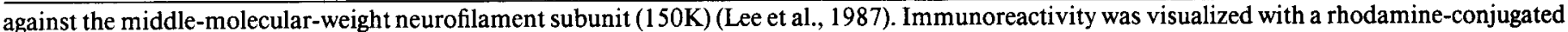

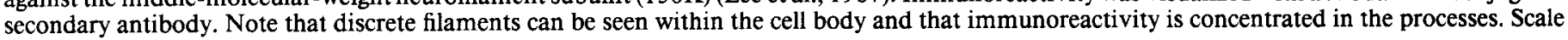
bar, $25 \mu \mathrm{m}$. 

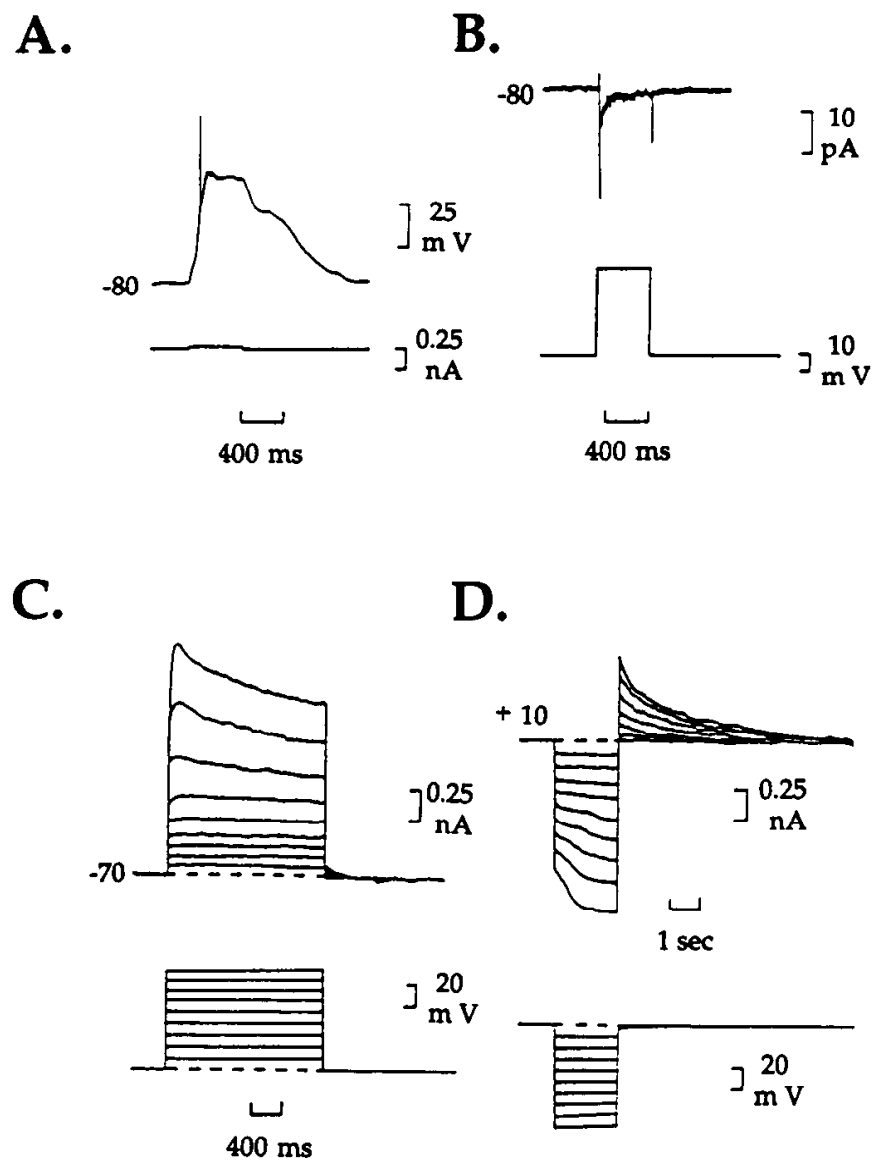

Figure 3. Membrane properties and ionic conductances expressed in retinoic acid-differentiated hippocampal hybrid cells (HN9.10e). A, An action potential and depolarizing afterpotential (upper trace) evoked by a depolarizing current injection (lower trace) and, $B$, inward current recorded under voltage-clamp (upper trace) induced by a depolarizing voltage step (lower trace) in the same cell held at $-80 \mathrm{mV}$. $C$ and $D$, Series of current (top traces) and voltage (lower traces) recorded in a voltage-clamped hybrid cell held at -70 and $+10 \mathrm{mV}$, respectively. $C$, Sustained and depolarizing voltage steps from a holding potential of

$70 \mathrm{mV}$, while in $D$, inactivating outward currents were recorded from $+10 \mathrm{mV}$ following $2 \mathrm{sec}$ prepulses to various potentials between -20 and $-100 \mathrm{mV}$. Note also in $D$ the activation of a time-dependent inwardly rectifying current with cell hyperpolarization.

manner during the hyperpolarizing prepulse. This current was recorded in 7 of 20 cells and was reduced by 1-2 mM cesium ions $\left(\mathrm{Cs}^{+}\right)$.

HN33.11p exhibited electrophysiological properties similar to HN9.10e. In addition, both lines decreased their mitotic rates and extended longer processes when differentiated with retinoic acid (data not shown). N18TG2 cells did not morphologically differentiate under these conditions (data not shown) and are not electrically excitable (Platika et al., 1985).

Expression of trophic activity by $H N$ cell lines. Media conditioned by 22 hippocampal cell lines or N18TG 2 cells were examined for effects on septal neuron CAT activity using the bioassay described above. With most of the cell lines tested, the conditioned medium $(100 \mu \mathrm{g} / \mathrm{ml}$ final protein concentration) increased septal CAT activity by no more than $75 \%$ compared with controls treated with $\mathrm{N} 2$ medium alone. However, when medium conditioned by the hippocampal cell line HN10e was added at $100 \mu \mathrm{g} / \mathrm{ml}$, CAT activity increased by over $300 \%$ com-

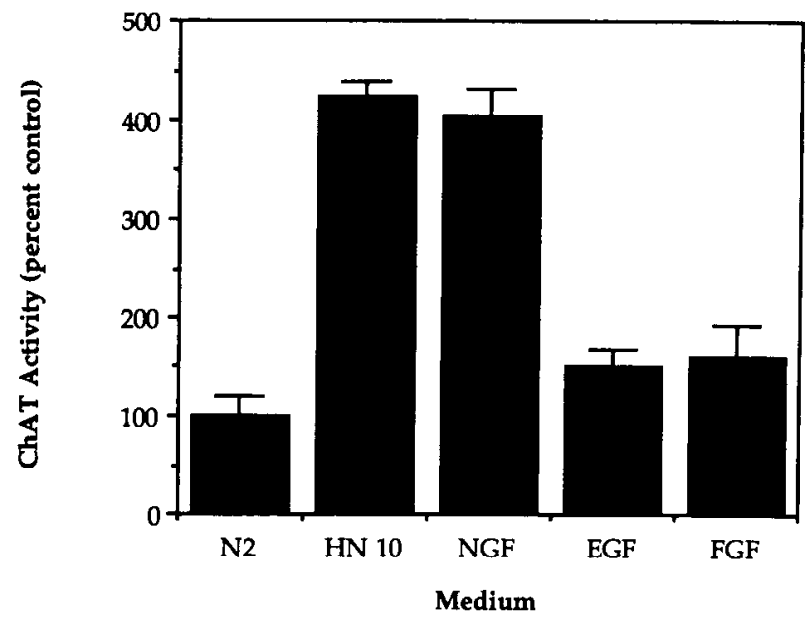

Figure 4. Effect of NGF, epidermal growth factor, basic fibroblast growth factor, and HN10e conditioned medium on septal CAT activity. Primary septal cells were cultured, as described in Materials and Methods, in the presence of $\mathrm{N} 2$ medium only (control), in the presence of NGF at $100 \mathrm{ng} / \mathrm{ml}$, in the presence of epidermal growth factor (EGF) at $1 \mathrm{~nm}$ final concentration, in the presence of basic fibroblast growth factor (FGF) at $1 \mathrm{nM}$ final concentration, or in the presence of $100 \mu \mathrm{g} /$ $\mathrm{ml}$ of HN10e conditioned medium. The CAT activity of the septal cells treated with each of the various reagents is cxpressed as a percentage of control (N2 medium alone). HN10e conditioned medium exhibited a significant increase in CAT activity compared with the control medium $(p=0.001)$. NGF resulted in an increase in CAT approximately $(p=0.001)$ equal to that of the HN10 conditioned medium. EGF and FGF did not have a significant effect on CAT activity under the conditions of the bioassay. Error bars indicate SEM.

pared with controls (Fig. 4). Three polypeptide growth factors were also tested for effects on septal cell CAT activity. NGF at $100 \mathrm{ng} / \mathrm{ml}$ resulted in an increase in CAT activity of $300 \%$ over controls, similar to the effect of $100 \mu \mathrm{g} / \mathrm{ml} \mathrm{HN10e}$ conditioned medium (Fig. 4). Epidermal growth factor and basic fibroblast growth factor, each at $1 \mathrm{~nm}$ final concentration, increased CAT activity to a lesser extent, 50 and $60 \%$ over controls, respectively (Fig. 4).

Because of the possibility that NGF might mediate the $\mathrm{HN} 10 \mathrm{e}$ effect on septal cell CAT activity, we directly measured the concentration of NGF in the HN10e conditioned medium. The final concentration of NGF in the conditioned medium-treated wells was less than $1 \mathrm{pg} / \mathrm{ml}$ (data not shown), over 10,000 -fold less than the concentration of exogenous, purified NGF required to achieve the same effect on CAT activity.

\section{Discussion}

To better understand neurochemical and trophic interactions within the cholinergic septohippocampal pathway, hippocampal cells from embryonic day 18 and postnatal day 21 mice were immortalized by fusing them to N18TG2 neuroblastoma cells. Several hybrid lines stably exhibit morphologies, electrophysiological behaviors, or trophic activities typical of primary hippocampal neurons. The neuronal origin of the cell lines is confirmed by their expression of neurofilaments, a class of intermediate filaments specific for neurons. When plated at moderately high densities, several hippocampal lines form cellular aggregations that extend processes attached to other aggregations rather than open spaces on the dish. These growth characteristics resemble those exhibited by primary neurons grown at similar densities and appear to reflect locally active 
trophic interactions. Ultrastructural studies of similarly derived lines indicate that the processes are neuritic growth cones with vesicular elements, numerous mitochondria, and a meshwork of microtubules and intermediate filaments (Hammond et al., $1989,1990)$. Since the parental N18TG2 cells exhibit none of these characteristics and only a subset of hybrid lines exhibit them, the neuronal properties expressed by hippocampal lines are likely to represent the expression of a cohort of neuronal genes rather than the activation of a random array of genes by hybridization (Davidson, 1978) (Table 1).

The hippocampal lines offer an important advantage over primary cultures of hippocampal neurons in that a continuous cell line can be maintained, allowing a unique opportunity for investigating the ionic conductances and other membrane properties of hippocampal neurons. Electrophysiological results indicate that differentiated hippocampal cell lines share membrane propertics with adult hippocampal ncurons. The action potential configuration, with the depolarizing afterpotential, resembles that previously observed in cultured slice preparations of the hippocampus (cf. Fig. 1 in Gähwiler and Brown, 1985). Both sustained and transient $\mathrm{K}^{+}$currents recorded in the hippocampal hybrid cells in the present study show similarities to those reported in a variety of adult and cultured hippocampal cell preparations. The time-dependent, Cs'-sensitive inwardly rectifying current activated by hyperpolarization is probably the "Q"-current $\left(I_{Q}\right)$ originally described in hippocampal cells and also reported in dissociated cultured cells. The presence of $I_{Q}$ is particularly significant since it has not been detected in other neuroblastoma derived hybrid cells (e.g., neuroblastoma $\times$ glioma hybrids: Brown and Higashida, 1988). The hippocampal lines can be used to examine the ionic and intracellular signaling mechanisms by which synaptic influences regulate hippocampal neuronal activity.

The hippocampal formation supports its cholinergic innervation from the septal region by promoting the expression of cholinergic markers, the survival of cholinergic septal neurons, and selective synaptogenesis (Gähwiler and Hefti, 1984; Gähwiler and Brown, 1985; Hsiang et al., 1987, 1988). Although the molecular basis of this influence is not completely understood, NGF plays an essential role since it is synthesized by hippocampal neurons and partially mimics the trophic effects of hippocampal cells via a receptor mediated mechanism (for review, see Whittemore and Seiger, 1987; see also Hartikka and Hefti, 1988, and Hsiang et al., 1989). The effects of NGF on septal neurons change during development. Neonatal rats respond to intraventricular infusions of NGF by dramatically increasing CAT activity in the septal region, but adults exhibit only a slight rise (Gnahn et al., 1983; Mobley et al., 1986). Similarly, cultured embryonic and early neonatal neurons increase CAT activity when exposed to exogenous NGF (Gnahn et al., 1983; Hartikka and Hefti, 1988; Hatanaka et al., 1988; Hsiang et al., 1989), whereas cultures derived from older animals exhibit no changes in activity (Hatanaka et al., 1988). Sensory and sympathetic neurons also exhibit an age-dependent response to NGF (for review, see Yankner and Shooter, 1982). Hence, the trophic factor influences which support the developing septohippocampal pathway may differ from those that maintain it in the adult.

Our results show that many hippocampal lines constitutively express NGF. Some of these lines also contain neurofilament proteins or exhibit electrophysiological behaviors typical of hippocampal neurons. The finding that neuronal hippocampal lines express NGF is consistent with in situ hybridization studies which have shown that neurons are the primary sites of NGF synthesis in the unlesioned hippocampus (Rennert and Heinrich, 1986; Ayer-LeLievre et al., 1988; Whittemore et al., 1988; Gall and Isackson, 1989). The high levels of NGF protein contained in the hippocampal lines may reflect the clonal nature of the lines as well as the age of the hippocampal tissue from which they were derived. NGF expression in situ rises dramatically from birth and reaches a developmental peak at approximately postnatal day 21 (Large et al., 1986). Similarly, hippocampal lines generated from postnatal day 21 synthesize higher levels of NGF protein than lines from embryonic day 18 tissue. Agedependent expression has also been observed for septal hybrid lines and CAT activity (Hammond et al., 1986, 1990; Lee et al., 1990).

In contrast to NGF protein, NGF mRNA is higher in hippocampal lines derived from embryonic tissue than postnatal tissue. Our finding that cultured murine hippocampal cells undergo a dramatic increase in NGF protein but not mRNA (Roback et al., 1990) suggests that the behavior of the hippocampal lines may not be an artifact of subcloning or hybridization. NGF expression in situ appears to be regulated by a variety of signals, including normal turnover in the hippocampus, septal afferents (Korsching et al., 1986; Weskamp et al., 1986), and electrical activity (Gall and Isackson, 1989), but expression in vitro is regulated only by normal turnover (Roback et al., 1990). Since NGF was not detected in the conditioned medium of the hippocampal lines or cells (unpublished observations), the high levels of NGF protein and relatively low mRNA levels may reflect an accumulation of NGF protein and subsequent downregulation of the NGF gene. Alternatively, the high levels of NGF mRNA in embryonic lines may result from anomalous transcription or processing of the mRNA transcript. The hippocampal lines described in the present study may thus be used as model systems for the study of NGF synthesis and regulation in the CNS. In this light, a particularly interesting finding is that cis elements within the NGF promoter govern the cell-specific and developmental expression of the NGF gene in the periphery (Alexander et al., 1989). Permanent cell lines derived from specific brain structures that synthesize NGF have not been previously reported.

NGF appears to act with an unknown number of other trophic factors since antibody-mediated neutralization of endogenous NGF in situ or in cocultures of septum and hippocampus does not dramatically decrease septal cholinergic markers, even when the antibodies are able to penetrate throughout the tissues (Gnahn et al., 1983; Hsiang et al., 1989). Several neurotrophic factors have been isolated from peripheral tissues (for review, see Walicke, 1989). Of these, only NGF and basic fibroblast growth factor are known to influence central cholinergic neurons. Intraventricular infusion of either factor attenuates the loss of axotomized septal cholinergic neurons (Hefti et al., 1984; Kromer, 1987; Anderson et al., 1988). In the CNS, brain extracts and wound cavities have been used to partially characterize cholinotrophic activities by several laboratories (Sekiguchi et al., 1975; Bostwick et al., 1987; Emerit et al., 1989). The only trophic factor to be purified from central tissues and extensively characterized is brain-derived neurotrophic factor (Barde et al., 1987). This factor supports peripheral neurons innervating the CNS.

The hippocampal cell lines, and immortalized neuronal tissue in general, provide a more readily available source of material 
for biochemical analyses than primary tissues. Biochemical analyses of such lines can be directed toward isolating the specific macromolecules which modulate trophic interactions between neurons and their targets. Their clonal nature increases the probability of identifying cell lines which express interesting trophic activities as well as the likelihood of successfully purifying and characterizing the molecule(s) responsible for the trophic activity [indeed, a rat sarcoma made possible the original identification of NGF (Levi-Montalcini, 1987)]. Recently, modified cell-immortalization strategies now permit the immortalization of cells from specific brain regions (Giotta and Cohn, 1982; Hammond et al., 1986, 1990; Bartlett et al., 1988; Cepko, 1988; Frederiksen et al., 1988; Lee et al., 1990) but have not been widely applied to regions known to elaborate trophic signals that participate in the establishment and maintenance of the synaptic circuitry of those regions. Since trophic interactions change as the nervous system develops, target tissues immortalized at different developmental stages would be particularly useful for isolating "neural trophic factors" preferentially expressed during specific developmental periods.

The ability of some of our embryonic and postnatal lines to synthesize large amounts of NGF suggests that novel trophic factors which influence septal neurons may be produced. Moreover, the hippocampal origin of the lines raises the possibility that identified factors may be target specific and underlie the specificity of the neural connections between septal and hippocampal neurons. Using a serum-free culture system, we found that medium conditioned by most hippocampal lines and by N18TG2 cells increased the CAT activity of cultured septal neurons by relatively modest amounts, up to $75 \%$ greater than controls. However, medium conditioned by HNlOe cells increased septal CAT activity by approximately 300\% (Fig. 5). The HN10e activity does not appear to represent a nonspecific effect of cellular proteins on septal cells in culture since other conditioned media with equivalent final protein concentrations do not result in similar increases in CAT. Furthermore, the lack of equivalent effect with N18TG2-conditioned medium suggests that $\mathrm{HN} 10 \mathrm{e}$ bioactivity may represent the expression of a hippocampal trait. The HN10e activity does not appear to be mediated by NGF. Direct quantitation of NGF by ELISA indicates that the concentration of NGF in HN10e-treated wells is over 10,000 -fold less than the concentration of purified, exogenous NGF required for a similar effect (Fig. 5). In addition, preliminary results indicate that the cholinotrophic activity of $\mathrm{HN} 10 \mathrm{e}$ is not affected by antibody-mediated neutralization of NGF but is sensitive to proteases and heat (unpublished observations). It also appears unlikely that epidermal growth factor or basic fibroblast growth factor are responsible for the trophic activity. In concentrations equal to or greater than those which have been found to enhance neuronal survival in other in vitro systems (Morrison et al., 1987; Walicke, 1989), epidermal growth factor and basic fibroblast growth factor have significantly less of an effect on septal CAT activity in our bioassay than does the $\mathrm{HN} 10 \mathrm{e}$ conditioned medium.

It will be of interest to examine the effects of differentiating agents as well as trophic factors on the hippocampal lines. Differentiating agents act through many different mechanisms to modulate the properties of the permanent cell lines. For example, retinoids and elevation of intracellular cAMP are frequently used to differentiate neuroblastoma lines (Nirenberg et al., 1983; Eddé and Darmon, 1985). Fibroblast growth factors and amyloid $\beta$ protein enhance the survival of cultured hip- pocampal neurons (Walicke, 1988; Whitson et al., 1989). Receptors for epidermal growth factor have recently been detected in the hippocampus and neocortex (Werner et al., 1988). Epidermal growth factor promotes the survival and differentiation of cultured cortical neurons (Morrison et al., 1987), but its function in the hippocampus unclear. Trophic influences of an unconventional nature may also be examined. Recently, electrical activity was shown to alter hippocampal NGF production (Gall and Isackson, 1989). Such studies will help us to understand the mechanisms by which these influences regulate hippocampal function.

Trophic cues operate throughout life to modulate neural function. These cues influence the properties of not only projecting neurons, but also target neurons. The identification of novel neurotrophic factors will provide a better understanding of the regulatory cues underlying the formation and maintenance of specific ncural pathways and may provide a rationale for the treatment of neurodegenerative diseases. The generation of hippocampal cell lines from various stages of development provides a useful tool to examine differentiating agents, trophic cues, and the excitable properties of hippocampal neurons.

\section{References}

Alexander JM, Hsu D, Penchuk L, Heinrich G (1989) Cell-specific and developmental regulation of a nerve growth factor-human growth hormone fusion gene in transgenic mice. Neuron 3:133-139.

Anderson KJ, Dam D, Lee S, Cotman CW (1988) Basic fibroblast growth factor prevents death of lesioned cholinergic neurons in vivo. Nature 332:360-361.

Ayer-LeLievre C, Olson L, Ebendal T, Seiger A, Persson H (1988) Expression of the $\beta$-nerve growth factor gene in hippocampal neurons. Science 240:1339-1341.

Barde YA, Davies AM, Johnson JE, Lindsay RM, Thoenen H (1987) Brain derived neurotrophic factor. Prog Brain Res 71:185-189.

Bartlett PF, Reid HH, Bailey KA, Bernard O (1988) Immortalization of mouse neural precursor cells by the c-myc oncogene. Proc Natl Acad Sci USA 85:3255-3259.

Bostwick JR, Appel SH, Perez-Polo JR (1987) Distinct influences of nerve growth factor and a central cholinergic trophic factor on medial septal explants. Brain Res 422:92-98.

Bottenstein JE, Sato G (1985) Cell culture in the neurosciences. New York: Plenum.

Bradford MM (1976) A rapid and sensitive method for the quantitation of microgram quantities of protein utilizing the principle of protein-dye binding. Anal Biochem 72:248-254.

Brown DA, Higashida H (1988) Voltage- and calcium-activated potassium currents by mouse neuroblastoma $\times$ rat glioma hybrid cells. J Physiol (Lond) 397:149-165.

Cepko C (1988) Immortalization of neural cells via oncogene transduction. Trends Neurosci 11:6-8.

Clegg DO, Bodary SC, Large TH, Shelton DL, Reichardt LF (1989) Quantitative measurement of nerve growth factor mRNA. In: IBRO handbook series: nerve growth factor (Rush RA, ed), pp 255-275. New York: Wiley.

Davidson RL (1978) Genetics of cultured mammalian cells, as studied by somatic cell hybridization. Natl Cancer Inst Monogr 48:21-30.

Eddé B, Darmon M (1985) Neural differentiation of pluripotent embryonal carcinoma cells. In: Cell culture in the neurosciences (Bottenstein JE, Sato G, eds), pp 274-285. New York: Plenum.

Emerit MB, Segovia J, Alho MJ, Wise BC (1989) Hippocampal membranes contain a neurotrophic activity that stimulates cholinergic properties of fetal rat septal neurons cultured under serum-free conditions. J Neurochem 52:952-961.

Finkel AS, Redman S (1984) Theory and operation of a single microelectrode voltage clamp. J Neurosci Methods 11:101-127.

Fonnum $F$ (1975) A rapid radiochemical method for the determination of choline acetyltransferase. J Neurochem 24:407-409.

Frederiksen K, Jat PS, Valtz N, Levy D, McKay R (1988) Immortalization of precursor cells from the mammalian CNS. Neuron 1: $439-448$. 
Gähwiler BH, Brown DA (1985) Functional innervation of cultured hippocampal neurones by cholinergic afferents from co-cultured septal explants. Nature 313:577-579.

Gähwiler BH, Hefti F (1984) Guidance of acetylcholinesterase-containing fibers by target tissue in co-cultured brain slices. Neuroscience 13:681-689.

Gall CM, Isackson PJ (1989) Limbic seizures increase neuronal production of messenger RNA for nerve growth factor. Science 245:758761 .

Giotta GJ, Cohn M (1982) Derivation of neural cell lines with Rous sarcoma virus. In: Neuroscience approached through cell culture, vol 1 (Pfeiffer SE, ed), pp 203-226. Boca Raton, FL: CRC Press.

Gnahn H, Hefti F, Heumann R, Schwab ME, Thoenen H (1983) NGFmediated increase of cholinc acctyltransfcrasc (ChAT) in the nconatal rat forebrain: evidence of a physiological role of NGF in the brain? Dev Brain Res 9:45-52.

Greene LA, Shain W, Chalazonitis A, Breakefield XO, Minna J, Coon HG, Nirenberg M (1975) Neuronal properties of hybrid neuroblastoma $\times$ sympathetic ganglion cells. Proc Natl Acad Sci USA 72:49234927.

Hamill OP, Marty A, Neher E, Sakmann B, Sigworth FJ (1981) Improved patch-clamp techniques for high-resolution current recording from cells and cell-free membrane patches. Pfluegers Arch 391:85100.

Hammond DN, Wainer BH, Tonsgard JH, Heller A (1986) Neuronal properties of clonal hybrid cell lines derived from central cholinergic neurons. Science 234:1237-1240.

Hammond DN, Lee HJ, Waincr BH (1989) Neuronal ultrastructural characteristics of a cholinergic cell line. Soc Neurosci Abstr 15:1331.

Hammond DN, Lee HJ, Tonsgard JH, Wainer BH (1990) Development and characterization of clonal cell lines from septal cholinergic neurons. Brain Res (in press).

Hartikka J, Hefti F (1988) Development of septal cholinergic neurons in culture: plating density and glial cells modulate effects of NGF on survival, fiber growth, and expression of transmitter-specific enzymes. J Neurosci 8:2967-2985.

Hatanaka H, Tsukui H, Nihonmatsu I (1988) Developmental change in the nerve growth factor action from induction of choline acetyltransferase to promotion of cell survival in cultured basal forebrain cholinergic neurons from postnatal rats. Dev Brain Res 39:85-95.

Hefti F, Dravid A, Hartikka J (1984) Chronic intraventricular injections of nerve growth factor clcvatc hippocampal choline acetyltransferase activity in adult rats with partial septo-hippocampal lesions. Brain Res 293:305-311.

Hsiang J, Wainer BH, Shalaby IA, Hoffmann PC, Heller A, Heller BR (1987) Neurotrophic effects of hippocampal target cells on developing septal cholinergic neurons in culture. Neuroscience 21:333343.

Hsiang J, Price SD, Heller A, Hoffmann PC, Wainer BH (1988) U1trastructural evidence for hippocampal target cell-mediated trophic effects on septal cholinergic neurons in reaggregating cell cultures. Neuroscience 26:417-431.

Hsiang J, Heller A, Hoffmann PC, Mobley WC, Wainer BH (1989) The effects of nerve growth factor on the development of septal cholinergic neurons in reaggregate cell cultures. Neuroscience 29:209223.

Korsching S, Heumann R, Thoenen H, Hefti F (1986) Cholinergic denervation of the rat hippocampus by fimbrial transection leads to a transient accumulation of nerve growth factor (NGF) without change in mRNA NGF content. Neurosci Lett 66:175-180.

Kromer LF (1987) Nerve growth factor treatment after brain injury prevents neuronal death. Science 235:214-216.

Large TH, Bodary SC, Clegg DO, Weskamp G, Otten U, Reichardt LF (1986) Nerve growth factor gene expression in the developing rat brain. Science 234:352-355.

Lee HJ, Elliot GJ, Hammond DN, Lee VM-Y, Wainer BH (1989) Expression of the mature array of neurofilament protein isoforms by a clonal cell line derived from the CNS. Soc Neurosci Abstr 15:327.

Lee HJ, Hammond DN, Large TH, Wainer BH (1990) Immortalized young adult ncurons from the septal region: generation and characterization. Dev Brain Res 52:219-228.

Lee VM-Y, Carden MJ, Schlaepfer WW, Trojanowski JQ (1987)
Monoclonal antibodies distinguish several differentially phosphorylated states of the two largest rat neurofilament subunits (NF-H and NF-M) and demonstrate their existence in the normal nervous svstem of adult rats. J Neurosci 7:3474-3488.

Levey AI, Armstrong DM, Atweh SF, Terry RD, Wainer BH (1983) Monoclonal antibodies to choline acetyltransferase: production, specificity, and immunohistochemistry. J Neurosci 3:1-9.

Levi-Montalcini R (1987) The nerve growth factor 35 years later. Science 237:1154-1162.

Mobley WC, Rutkowski JL, Tennekoon GI, Gemski J, Buchanan K, Johnston MV (1986) Nerve growth factor increases choline acetyltransferase activity in developing basal forebrain neurons. Mol Brain Res 1:53-62.

Morrison RS, Kornblum HI, Leslie FM, Bradshaw RA (1987) Trophic stimulation of cultured neurons from neonatal rat brain by epidermal growth factor. Science 238:72-75.

Nirenberg M, Wilson S, Higashida H, Rotter A, Krueger K, Busis N, Ray R, Kenimer JG, Adler M (1983) Modulation of synapse formation by cyclic adenosine monophosphate. Science 222: 794-799.

Paige CJ, Wu GE (1989) The B cell repertoire. FASEB J 3:18181824.

Platika D, Boulos MH, Baizer L, Fishman MC (1985) Neuronal traits of clonal cell lines derived by fusion of dorsal root ganglia neurons with neuroblastoma cells. Proc Natl Acad Sci USA 82:3499-3503.

Rennert PD, Heinrich G (1986) Nerve growth factor mRNA in brain: localization by in situ hybridization. Biochem Biophys Res Commun 138:813-818

Roback JD, Large TH, Otten U, Wainer BH (1990) Nerve growth factor expression in the developing hippocampus isolated in vitro. Dev Biol 137:451-455.

Sakmann B, Neher E (1983) Single-channel recording. New York: Plenum.

Scott J, Selby M, Urdea M, Quiroga M, Bell GI, Rutter WJ (1983) Isolation and nucleotide sequence of a $\mathrm{cDNA}$ encoding the precursor of mouse nerve growth factor. Nature 302:538-540.

Sekiguchi T, Sekiguchi F, Tomii S (1975) Genetic complementation in hybrid cells derived from mutagen-induced mouse clones deficient in HGPRT activity. Exp Cell Res 93:207-218.

Staats J (1980) Standardized nomenclature for inbred strains of mice: seventh listing. Cancer Res 40:2083-2128.

Vantini G, Schiavo N, Di Martino A, Polato P, Triban C, Callegaro L, Toffano G, Leon A (1989) Evidence for a physiological role of nerve growth factor in the central nervous system of neonatal rats. Neuron 3:267-273.

Walicke PA (1988) Basic and acidic fibroblast growth factors have trophic effects on neurons from multiple CNS regions. J Neurosci 8: 2618-2627.

Walicke PA (1989) Novel neurotrophic factors, receptors, and oncogenes. Annu Rev Neurosci 12:103-126.

Werner MH, Nanney LB, Stoscheck CM, King LE (1988) Localization of immunoreactive epidermal growth factor receptors in human nervous system. J. Histochem Cytochem 36:81-86.

Weskamp $G$, Otten $U$ (1987) An enzyme-linked immunoassay for nerve growth factor (NGF): a tool for studying regulatory mechanisms involved in NGF production in brain and peripheral tissues. J Neurochem 48:1779-1786.

Weskamp G, Gasser UE, Dravid AR, Otten U (1986) Fimbria-fornix lesion increases nerve growth factor content in adult rat septum and hippocampus. Neurosci Lett 70:121-126.

Whitson JS, Selkoe DJ, Cotman CW (1989) Amyloid beta protein enhances the survival of hippocampal neurons in vitro. Science 243 $1488-1490$.

Whittemore SR, Seiger A (1987) The expression, localization and functional significance of $\beta$-nerve growth factor in the central nervous system. Brain Res Rev 12:439-464.

Whittemore SR, Friedman PL, Larhammar D, Persson H, GonzalezCarvajal M, Holets VR (1988) Rat $\beta$-nerve growth factor sequence and site of synthesis in the adult hippocampus. J Neurosci Res 20 : 403-410.

Yankner BA, Shooter EM (1982) The biology and mechanism of action of nerve growth factor. Annu Rev Biochem 51:845-868. 